\title{
Needs Assessment of Academic Communities in Panabo City Division: Input to a Sustainable Community Extension Programs of the Institute of Education
}

\author{
Ronald S Decano*, Jean D Centina, Ann Cherry C Cereno, John Rae V Duran, Evelyn J Lumaday and Ma Kristine \\ A Patarata
}

Davao del Norte State College, Philippines

Submission: July 03, 2018; Published: August 27, 2018

*Corresponding author: Ronald S Decano, Davao del Norte State College, Philippines, Email: ronald.decano@dnsc.edu.ph

\begin{abstract}
The K to 12 program of the Department of Education (DepEd) poses problems especially on the part of the secondary school teachers. There could be mass hiring of basic education teachers to meet the demand of the possible influx of students. Some teachers might be hired and asked to teach subject outside of their fields. This led the researchers to delve on the academic needs and issues of the secondary school teachers in Panabo City through needs analysis. The goals of the study were to identify the issues and challenges of the secondary teachers; and devise an institutionalize extension programs that cater the academic needs of the school community. The study was anchored on the community development theory of Allison Tan that focuses and mitigates on the needs and issues of the oppressed people of the community. The researchers employed both the quantitative and qualitative designs. The researchers utilized survey questionnaires and focus group discussion in collecting relevant data. The needs assessment study revealed that most secondary teachers were male ranging 25 years old and below; most of them were in fixed term contract or probationary; finished on their bachelor's degrees; and had served for a year. Furthermore, they had found out that the immediate concern of the participants is to attend training that enhances their capacity as teachers. The researchers recommended that the Institute of Education should establish an extension program that caters the prominent needs of the teachers through i.Teach extension program (Integrated, Training, Education, Analysis, Communication, and Homemaking).
\end{abstract}

\section{Technical Report}

\section{Introduction}

Davao del Norte State College (DNSC) envisions to be the premier higher learning institution which provides equitable access, quality, relevant and environment friendly programs particularly in the community extension for a productive, sustainable and progressive society. One of its institutes, the Institute of Education also envisions to be a premier producer of world-class quality educators equipped with requisite knowledge in general education, professional education, specialized courses and necessary skills and values in research and extension. The institute also articulates the relationship of education to larger historical, social, cultural and political processes among stakeholders and the community where it belongs.

In our commitment to provide better services to our clientele, the Institute of Education (IEd) conducted a research entitled "Needs Assessment of Academic Communities in Panabo City: Input to Sustainable Community Extension Programs of the Institute of Education". This study aimed to provide both quantitative and qualitative information on social, economic and educational status of the respondents under study. This also aimed to pursue lifelong learning for personal and professional growth, establish linkages among stakeholders gearing towards quality and excellence and develop curricular programs that will cater to the needs of teachers.

The Philippine education system is in transition. This may result to a lower influx of student enrolment in the tertiary level because secondary school graduates will take two years of senior high school before going to college. Eventually, this may lead to lesser academic load for tertiary level teachers or in the worst-case scenario, possible retrenchment of faculty members. Measures to preserve human resources can be done by providing opportunities for faculty development, realignment and upgrading of the curriculum, improvement of facilities and instructional delivery systems, and a revisit to operations particularly in the areas of research and extension, all towards better quality and excellent educational services. Some of them will opt to go for advanced studies, specialized training or may engage in activities which demand their expertise and skills.

A community needs assessment can be defined as the gap between what is known and what should be known in academic communities of Panabo City Division particularly in secondary level. This is done to identify the problems encountered by the secondary school teachers to improve their knowledge, skills 
and attitudes. Needs assessments can go beyond what is already known about educational practices and add a snapshot of what is actually happening at present.

To institutionalize all the community extension activities of the school, community extension office should be created where the students, faculty members and administrative staff could share their resources and their expertise and be part of the school social involvement program. Thus, community extension service operates through self-support, self-reliance, self-sustaining, and self-propelling principles. Through people's participation, well-planned programs should be consciously taken into consideration.

Needs assessment survey is intended to categorize the predicaments experienced in the society and to surmise elucidations on alleviating these problems. Furthermore, this research will provide a constructive starting point on programs designed to correct the disparity between the ideal and observed states of the project [1].

A research about needs assessment on academic needs of the community is needed to be done in order to identify what are the immediate pre-requisite of education in the community. Through establishing the premise, it will serve as the framework for the designed program and the program will become more efficient for it caters the immediate problem. Furthermore, it is observed that the institution has less sustainability on its research projects through extension programs. Hence, it will provide hallmark on the institution. Thus, this research will not only enlighten the community's intellectual needs, but also provide framework in conducting extension programs to satisfactorily cater the needs of the community.

This study investigated academic communities which seldom received invitation from the Department of Education for training due to lack of financial capacity. Sustainable extension programs can be designed to help accommodate secondary school teachers for further enhancement and to keep abreast on the new trends in education. Extension program is best attained when needs assessment is conducted beforehand. It is advised that community needs assessments are conducted prior to the program planning and implementation [2]. Thus, it is important to undergo needs assessment on academic communities first before taking action in addressing these needs.

\section{Theoretical Framework}

The study is grounded on Community Development Theory by Allison Tan which states that the most practical framework for social workers seeking lasting change for individuals, communities and the societies in which they live. It focuses on the centrality of oppressed people in the process of overcoming externally imposed social problems. This theory is community development work because by the mere fact of the definition it speaks for itself. The theory could be adapted to other disciplines like Neighborhood Development. This will ensure that public and social services are meeting community needs and appropriate services are being initiated [3].

\section{Objectives}

This research began by looking at the necessity to undertake needs assessments for academic communities in Panabo City Division. In the light of the growing awareness of professionals in the community, this research sets out to explore, delineate and critically analyze the various approaches to community needs assessment, to facilitate a greater understanding of their strengths and weaknesses. It commences by highlighting its complex nature and attempting to define what is meant by needs assessment from the differing perspectives in the area.

This research is conducted to provide quantitative and qualitative information on social, economic and educational status of the academic communities of Panabo City Division. The information will be used by the Institute of Education to come up with a holistic and sustainable extension program customized to the needs of the different stakeholders as beneficiaries.

Specifically, it answered the following objectives:

i. Describe the socio-economic profiles of the respondents in terms of:
a) sex;
b) age;
c) employment status;
d) highest educational qualification; and
e) length of service;

ii. Determine the number of respondents who actively participated in any of the following kinds of professional developments in terms of:

a) Courses/workshop;

b) Education conferences or seminars;

c) Qualification program;

d) Observation visit to other schools;

e) Participation in a network of teachers formed specifically for the professional development of teachers; and

f) Individual or collaborative research on a topic of interest to you professionally.

iii. Ascertain the impact of these activities on teachers' development.

iv. Identify the issues and challenges encountered by the teachers in the academe.

v. Devise and institutionalize a community extension program of the Institute of Education to sustain the academic communities of Panabo City Division. 


\section{Methodology}

This section presents the appropriate research design, respondents, instruments, procedures for data collection and data analysis.

\section{Research design}

This Needs Assessment Survey utilized several data collection procedures using both quantitative and qualitative methods. Quantitative method done through survey included demographic and socio-economic profiling whereas qualitative method aimed at collecting information from secondary school teachers and school administrators in Panabo City Division regarding the problems they have encountered in their respective workplaces through focus group discussion and on the needs of the academic community in terms of basic educational provisions.

\section{Research respondents}

The Needs Assessment survey was administered in sample secondary schools in Panabo City Division. There were twelve (12) public and nine (9) private secondary schools in the division. However, due to the scarcity of resources, the research team decided to choose six (6) public and five (5) private secondary schools. The manner of choosing the desired number of schools in both public and private schools was done through lottery method. In choosing for the respective participants per secondary school, total enumeration was utilized to maximize participations among respondents.

\section{Research instruments}

School Teacher and Administrators' Questionnaire was administered to select secondary schools in Panabo City Division. The schools were as follows: Little Panay National High School, Francisco Adlaon Learning Institute, North Davao Colleges, San Vicente National High School, Quezon National High School, Panabo Christian School, and Panabo Faith Mission Academy [4]. This questionnaire was modified in order to determine the relevant profiles of the teachers and suit to their academic needs when it comes to professional development. The said questionnaire was validated by experts.

\section{Data Analysis}

Frequency and percentage distributions were considered as statistical treatment to analyze the demographic and socioeconomic profiles of the respondents. For the qualitative data, simple data reduction was employed to generate relevant information derived from the focus group discussions.

\section{Results and Discussions}

The presentation of the findings of the study are based on the sequence in research objectives.

\section{Socio-economic profiles of the respondents}

Table 1 shows the socio-economic profiles of the secondary school teachers in Panabo City Division. First profile of respondents is in terms of sex. Male consists of 61 respondents or $65.6 \%$ while female has 32 respondents or $34.4 \%$.
Table 1: Socio-economic Profiles of the Respondents.

\begin{tabular}{|c|c|c|}
\hline Profile & Frequency & Percentage \\
\hline \multicolumn{3}{|l|}{ Sex } \\
\hline Male & 61 & 65.6 \\
\hline Female & 32 & 34.4 \\
\hline \multicolumn{3}{|l|}{ Age } \\
\hline $\begin{array}{c}\text { Under } 25 \text { years } \\
\text { old }\end{array}$ & 54 & 58.1 \\
\hline 25-29 years old & 23 & 24.7 \\
\hline 30-39 years old & 13 & 14 \\
\hline $\begin{array}{c}40 \text { years and } \\
\text { above }\end{array}$ & 2 & 2.2 \\
\hline \multicolumn{3}{|l|}{$\begin{array}{c}\text { Employment } \\
\text { Status }\end{array}$} \\
\hline Permanent & 15 & 16.1 \\
\hline $\begin{array}{c}\text { Fixed Term } \\
\text { Contract }\end{array}$ & 70 & 75.1 \\
\hline \multicolumn{3}{|l|}{$\begin{array}{l}\text { Educational } \\
\text { Attainment }\end{array}$} \\
\hline Bachelor's Degree & 77 & 82.8 \\
\hline Master's Degree & 8 & 8.6 \\
\hline $\begin{array}{l}\text { Doctorate's } \\
\text { Degree }\end{array}$ & 4 & 4.3 \\
\hline \multicolumn{3}{|l|}{ Length of Service } \\
\hline Below One Year & 45 & 48.4 \\
\hline 1-2 years & 20 & 21.5 \\
\hline 3-5 years & 19 & 20.4 \\
\hline 6-10 years & 6 & 6.5 \\
\hline $\begin{array}{c}10 \text { years and } \\
\text { above }\end{array}$ & 3 & 3.4 \\
\hline
\end{tabular}

Most of the respondents in terms of gender are male. In the profile of respondents in terms of age; out of 93 respondents, there are 54 who are under 25 years old or $58.1 \%$; 23 respondents are $25-29$ years old or $24.7 \%$; 13 respondents are 30 -39 years old or $14.0 \%$; 40 - 49 years and above have only three respondents or $3.4 \%$. Majority of the respondents are under 25 years old. In the profile of respondents in terms of current employment status; out of 93 respondents, 15 respondents are under permanent employment (an on-going contract with no fixed end-point before the age of retirement) or $16.1 \%$ and 70 respondents are under fixed term contract for a period of more than 1 school-year +3 fixed-term contract for a period of 1 school year or less or $75.3 \%$.

The preceding table also shows the educational attainment of the respondents, 77 out of 93 respondents are bachelor's Degree graduate or $82.8 \%, 8$ respondent are Masters graduate or $8.6 \%, 3$ respondents are Doctorate Graduate or $3.2 \%$, and 1 respondent $0 \mathrm{r} 1.1 \%$ who has double doctorate. In addition, there are 4 or $4.3 \%$ who missed to answer the question. 
It also presents the profile of the respondents in terms of the length of service as a teacher where possible excluded extended periods of absence. Out of 93 respondents, 45 are in the 1 st year of teaching or $48.4 \% ; 20$ respondents are under 1-2 years of teaching or 21.5\%; 19 respondents are under 3-5 years of teaching or $20.4 \%$ while 6 respondents are 6-10 years in teaching or $6.5 \%, 2$ respondents are under $11-15$ years in teaching or $2.2 \%$; no respondent who is under $16-20$ years and 1 respondent for more than 20 years in teaching or $1.1 \%$.

\section{Frequency of the respondents who actively participated in any of the following kinds of professional development}

Table 2 shows the frequency of the respondents who actively participated in any of the following kinds of professional development.

Table 2: Frequency of those who availed Professional Development Activities.

\begin{tabular}{|c|c|c|c|}
\hline \multirow{2}{*}{$\begin{array}{c}\text { Professional Development } \\
\text { Activities }\end{array}$} & \multicolumn{2}{|c|}{ Frequency } & \multirow{2}{*}{ Percentage } \\
\cline { 2 - 3 } & Yes & No & \\
\hline $\begin{array}{c}\text { Courses/workshop (e.g. on subject } \\
\text { matter or methods and/or other } \\
\text { education-related topics) }\end{array}$ & 76 & 16 & 82.6 \\
\hline Education conferences or seminars & 63 & 30 & 67.7 \\
\hline $\begin{array}{c}\text { Qualification Program (degree } \\
\text { program) }\end{array}$ & 38 & 51 & 42.7 \\
\hline Observation visits to other schools & 37 & 54 & 40.7 \\
\hline $\begin{array}{c}\text { Participation in a network of } \\
\text { teachers formed specifically for } \\
\text { the professional development of } \\
\text { teachers }\end{array}$ & 48 & 42 & 53.3 \\
\hline $\begin{array}{c}\text { Individual or collaborative research } \\
\text { on a topic of interest to you } \\
\text { professionally }\end{array}$ & 63 & 52 & 42.9 \\
\hline
\end{tabular}

Table 2 shows the participation of the respondents in terms of Courses/ Workshop. Their participation is on the subject matter or methods and/or other education-related topics. Out of 93 respondents 76 respondents answered Yes or 81.7\%, 16 respondents answered No or $17.2 \%$ and 1 respondent missed to answer or $1.1 \%$.

In the participation of the respondents in terms of Educational Conferences or seminars, out of 93 respondents 63 respondents answered Yes or $67.7 \%$ and 30 respondents answered No or $32.3 \%$. In terms of Qualification program basically their pursuing graduate studies, thirty-eight (38) answered "Yes" or $40.9 \%$ and 51 respondents answered "No" or $54.8 \%$ and 4 respondents missed to answer [5].

Moreover, in terms of observation visit to other schools thirty-seven (37) of them answered "Yes" or 39.8\% and 54 respondents answered "No" or $58.1 \%$ and 2 respondents missed to answer. Furthermore, in participation in a network of teachers formed specifically for the professional deviation of teachers, forty-eight (48) of them answered "Yes" or 51.6\% and 42 respondents answered "No" or $45.2 \%$ and 3 respondents or $3.2 \%$ missed to answer.
Finally, in terms of their participation in individual or collaborative research on a topic of interest to the respondents professionally, thirty-nine (39) or roughly $42.9 \%$ responded "Yes" and the remaining 52 responded "No".

\section{Frequency of impact of professional development activities}

Table 3 presents the impact of the identified professional activities in their profession as teachers.

Table 3: Frequency of Impact of Professional Development Activities.

\begin{tabular}{|c|c|c|c|c|c|}
\hline \multirow{2}{*}{$\begin{array}{l}\text { Professional } \\
\text { Development } \\
\text { Activities }\end{array}$} & \multicolumn{4}{|c|}{ Frequency (Impact) } & \multirow{2}{*}{$\begin{array}{l}\% \text { (Large } \\
\text { Impact) }\end{array}$} \\
\hline & No & Small & Moderate & Large & \\
\hline $\begin{array}{l}\text { Courses/workshop } \\
\text { (e.g. on subject } \\
\text { matter or methods } \\
\text { and/or other } \\
\text { education-related } \\
\text { topics) }\end{array}$ & 2 & 7 & 19 & 44 & 61.1 \\
\hline $\begin{array}{c}\text { Education } \\
\text { conferences or } \\
\text { seminars }\end{array}$ & 5 & 4 & 20 & 36 & 55.4 \\
\hline $\begin{array}{c}\text { Qualification } \\
\text { Program (degree } \\
\text { program) }\end{array}$ & 6 & 3 & 13 & 21 & 48.8 \\
\hline $\begin{array}{l}\text { Observation visits } \\
\text { to other schools }\end{array}$ & 7 & 3 & 19 & 16 & 35.6 \\
\hline $\begin{array}{l}\text { Network of } \\
\text { teachers formed } \\
\text { specifically for } \\
\text { the professional } \\
\text { development of } \\
\text { teachers }\end{array}$ & 6 & 5 & 23 & 22 & 39.3 \\
\hline $\begin{array}{l}\text { Individual or } \\
\text { collaborative } \\
\text { research on a topic } \\
\text { of interest to you } \\
\text { professionally }\end{array}$ & 5 & 4 & 18 & 18 & 40 \\
\hline
\end{tabular}

Table 3 presents the impact of Courses / Workshops to the respondents. It reveals that out of 93 respondents, 2 respondents answered, "no impact" or $2.2 \%, 7$ respondents answered, "A small Impact" or 7.5\%, 19 respondents answered, "A moderate Impact "or 20.4\%, 44 respondents answered" A large Impact "or $47.3 \%$ and 21 respondents or $22.6 \%$ to missed to answer.

The impact of Education conferences/seminars to the respondents, only five (5) answered "No Impact" or 5.4\%, 4 respondents answered "A small impact or 4.3\%, 20 respondents answered "A moderate Impact" or 21.5\%, 36 respondents answered "A Large Impact" or $38.7 \%$ and 28 respondents or $30.1 \%$ missed to answer.

In the impact of Qualification program to the respondents, six (6) respondents answered "No Impact or 6.5\%, 3 respondents answered "A small Impact" or 3.2\%, 13 respondents answered "A moderate impact" or $14.0 \%, 21$ respondents answered "A large Impact" or $22.6 \%$ and 50 respondents missed to answer.

In the impact on Observation visits to other school, seven (7) respondents answered "No Impact" or $7.5 \%, 3$ respondents 
answered "A small Impact" or 3.2\%, 19 respondents answered "A moderate Impact or 20.4\%, 16 respondents answered "A large Impact" or $17.2 \%$ and 48 respondents or $51.6 \%$ missed to answer.

Table 3 also shows the impact of respondents participation in a network of teachers formed specifically for the professional development of teachers, out of 93 respondents, six (6) respondents answered "No Impact" or 6.5\%, 5 respondents answered "A small Impact" or 5.4\%, 23 respondents answered "A moderate Impact or 24.7\%, 22 respondents answered "A large Impact" or $23.7 \%$ and 37 respondents or $39.8 \%$ missed to answer.

Lastly, the impact of individual or Collaborative research on a topic of interest to the respondents professionally, five (5) respondents answered, "No Impact" or 5.4\%, 4 respondents answered" A small Impact" or 4.3\%, 18 respondents answered, "A moderate Impact" and "A large Impact" or $19.4 \%$ and 48 respondents or $51.6 \%$ missed to answer.

\section{Issues and challenges encountered by the teachers in the academe}

This study also intended to explore various issues and challenges encountered by secondary school teachers in their respective workplaces. This is an approach to research that facilitates exploration of a phenomenon within its context, using a variety of data sources. In generating for the themes, we assumed to be axiological wherein we observed the role of values in research. In other words, all standard operating procedures were observed which included the strict implementation of the ethical considerations.

This approach which was done through focus group discussion simply gathered the participants' description of how various issues and challenges bombarding the secondary school teachers in their quest to provide better education to their learners. Some information was reflected on their written or oral self-report and their aesthetic expressions. It focused on the subjectivity of reality, continually pointing out the need to understand how these teachers view them and the world around them [6].

Particular letters of authorization, assent and the nature of the study were made known to the participants. After the assent was granted, plan for the meetings included the participants were conducted. Since this involved a serious matter in the academe to reveal, we ensured the participants confidentiality of the information gathered.

While numerous qualitative researchers understood that there are no set moral guidelines in place for qualitative researches to take after, best practices directed that careful and intelligent methodologies ought to be at the front line of the review outline. To that end, our connection with the participants would include open doors for inquiries, elucidation of processes and affirmation of privacy.
In gathering qualitative data, the role of the researcher should have to be established because there could be contamination of information that might be developed in the course of the study. Basically, our role was to establish the phenomenon under investigation, the objectives to attain and appropriate questions to be asked, collection and careful analysis tools, ethical consideration was observed, and how the reports were reported and disseminated.

The succeeding paragraphs are the results of the focus group discussion. There were about fifteen (15) secondary school teachers participated in the study. The questions raised were focused on the strengths and weaknesses of teachers when it comes to providing instructions to their learners in their respective workplaces. They started talking about their expertise. Most of them revealed that in terms of teaching, there is no doubt they can give their best in the subject. They are consistently updating themselves to the latest trends by taking extra efforts of reading and attending training and workshop related to their fields. Some of them cascaded their best practices so that others may be emulated to do the same in their school.

When asked about the problems they encountered in their respective schools, these are as follows:

a) Lack of facilities especially in ICT

b) Small budget allocation of school MOOE

c) Lack of training workshop on classroom management strategies, methodologies and innovations

d) Limited teachers' engagement to writing quality action research

e) Weak schools' participation in different competitions

f) Students' discipline

g) Limited teacher's participation in relevant trainings and workshop due to unavailability of funds

The central idea of coming up with this needs assessment survey is to gather.

relevant information as to how the Institute of Education of Davao del Norte State College form its research-based community extension program that will benefit the entire community. In our first phase of the study, we considered the secondary school teachers as our beneficiaries because it also calls the individual expertise of the faculty in the institute. We have our pool of experts who will be tapped to provide trainings to the teachers. Among the current needs of the participants as derived from the focus group discussion are the following:

a) Seminar-workshop on the Development of Instructional Materials.

b) Training-workshop on making action research.

c) Seminar/training on teaching strategies for least learned competencies. 
d) Classroom management seminar.

e) Instructional enhancement for Teachers.

f) Curriculum mapping.

g) Data Analysis (Statistical treatment).

h) Finding Appropriate TLA's in teaching Mathematics.

i) Training on ICT Integration in Teaching mathematics.

j) Training and workshop on the Update of individual knowledge of the Subject Taught.

k) Training on Different Strategies in Teaching.

l) Update on 21st Century ICT Integration .

m) Seminar/training about different technologies.

Numbers 1 to 11 can be facilitated by the Institute of Education because basically these needs are academic by nature. The faculty in the institute are already trained in the new trends in the 21st century education. However, numbers 12 to 13 are needs that can be best facilitated by the Institute of Information Technology.

\section{Conclusions and Recommendations}

\section{Conclusion}

The needs assessment of academic communities in Panabo City Division was conducted to help the Institute of Education formulate its sustaining community extension programs. Since our expertise is basically educational by nature, the academic community particularly the secondary school teachers in the division were chosen to be the respondents for the sociodemographic profiling and our participants for the focus group discussion.

There were two phases of the study. First phase was gathering of the quantitative data of the respondents which included their sex, age, employment status, educational attainment and length of service. School Teacher and Administrators' Questionnaire was administered during the first phase.

Quantitative analysis of the data reveals that most secondary school teachers were males and younger whose age ranging from 25 years old and below. Most of them were in the fixed term contract or probationary, bachelor's degree and whose length of service fall below one year.

Second phase was done through focus group discussion. The discussion focused on the strengths and weaknesses of the teachers in delivering the instructions. We also asked them on their present needs which the institute could help. Among the needs of the participants as derived from the focus group discussion were the following:

a) Seminar-workshop on the Development of Instructional Materials.

b) Training-workshop on making action research. c) Seminar/training on teaching strategies for least learned competencies.

d) Classroom management seminar.

e) Instructional enhancement for Teachers.

f) Curriculum mapping.

g) Data Analysis.

h) Finding Appropriate TLA's in teaching Mathematics.

i) Training on ICT Integration in Teaching mathematics.

j) Training and workshop on the Update of individual knowledge of the Subject Taught.

k) Training on Different Strategies in Teaching.

l) Update on $21^{\text {st }}$ Century ICT Integration.

m) Seminar/training about different technologies (Figure $1 \& 2)$.
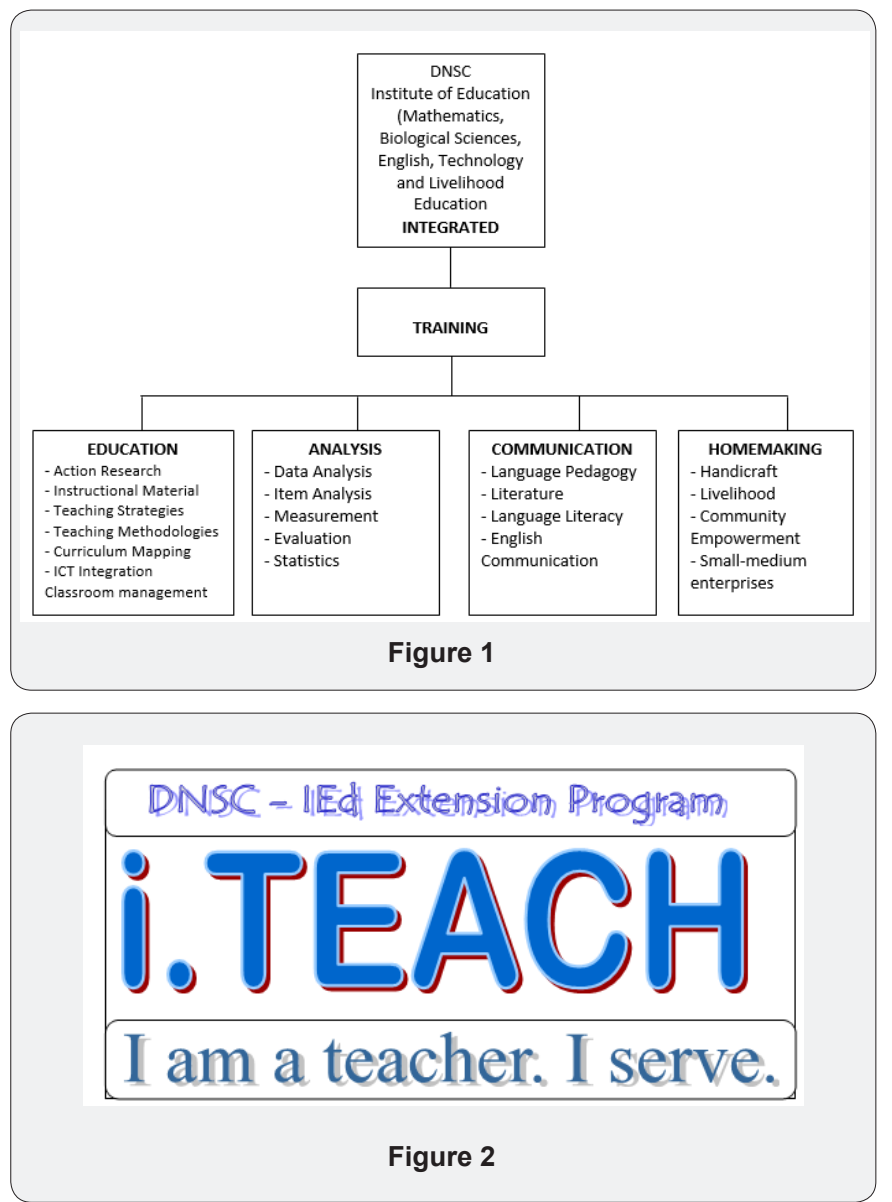

\section{Recommendation}

Based on the findings of the study, the proponents recommend the Institute of Education to form a sustainable community extension programs that will help the secondary school teachers enhance their capability in educational aspect, measurement, analysis, research, communication and even about homemaking. The program will run in two phases; one 
during the first semester of July in particular and second phase should be done in the second semester preferably in January. The proponents also recommend the Institute's extension programs to be named i.TEACH as it describes our blistering passion for teaching [7].

\section{i -Integrated}

Institute of Education consists of disciplinal faculty members who are expert in the fields of Mathematics, English, Biological Sciences and Technology and Livelihood Education. Integrated, as Merriam-Webster defines it, as having different parts working as a unit. We are bound to integrate in the call for service, allowing each one to contribute for the success of the program.

\section{T - Training}

The best way to measure the effectiveness of a certain program depends on the ability of the recipients to internalize and apply in actual scenario. This ability could not only be acquired through listening in a symposium. Relevant training should be conducted to ensure that the skills are actually performed. The training should encompass based on the needs for capability building and enhancement in the following areas:

\section{E - Education}

The training in education includes Instructional Materials Development, Teaching strategies and methodologies, Curriculum mapping and designs, syllabus making using Outcomes-based education, Capacity building in the field of expertise, classroom management and many more.

\section{A - Analysis}

The training in analysis includes statistical treatment of data, action research, measurement and evaluation, item analysis, quantitative and qualitative researches, univariate and multivariate analysis.

\section{C - Communication}

The training in communication includes language proficiency, English as second language, pangunahing elemento ng wikang Filipino, and others.

\section{H - Homemaking}

The training in homemaking includes handicraft making, home accessories, production of small enterprises and any community livelihood programs.

Since the program entails greater responsibility, the proponents recommend the dean of the institute to designate a coordinator who is tasked to make the program sustaining and efficient.

i.TEACH Community Extension Program of the Institute of Education is an expression of the institute's mission to establish mutual working relationship to a larger community where it belongs. In our desire to take effect changes in the academic communities in Panabo City division, this program is a friendly reminder of our motto: I am a Teacher. I serve. i.TEACH

\section{References}

1. Chondoka AY (1999) Needs Assessment Survey on Radio Programmes for out-of school children in Misisi, Chawama, Ng'ombe, Mtendere, Bauleni, Chipata, Kabwata and George Townships in Lusaka and Chongwe. Ministry of Education.

2. Commonwealth Secretariat (1980) Participation, Learning and Change. London, UK

3. Commonwealth Secretariat Commonwealth Secretariat (1999) Diversifying Education Delivery Systems: Reviving Discourse on the Formal/Nonformal Interface Workshop Report on Nonformal Education. Gaborone, Botswana.

4. Coombs PH (1985) The world Crisis in Education. The view from the eighties. Oxford University Press, New York, USA.

5. Lusaka Ministry of Education (1992) Focus on Learning: strategies for the development of school education in Zambia, Ministry of Education (1996), Educating our Future, Lusaka Ministry of Education (1999). Education for All 2000 Assessment.

6. Lusaka Mumba EC (1989) Delivery systems and Organization of Nonformal education in Zambia. International Journal of University Adult Education 33(3): 45-54.

7. Siamwiza R (1999) A Situation Analysis of Policy and Teaching HIV/ AIDS Prevention in Educational Institutions in Zambia, Lusaka, UNESCO, World Education forum (2000). The Dakar Framework for action: Education for all, Meeting our Collective Commitment.

\section{Your next submission with Juniper Publishers} will reach you the below assets

- Quality Editorial service

- Swift Peer Review

- Reprints availability

- E-prints Service

- Manuscript Podcast for convenient understanding

- Global attainment for your research

- Manuscript accessibility in different formats

( Pdf, E-pub, Full Text, Audio)

- Unceasing customer service

Track the below URL for one-step submission https://juniperpublishers.com/online-submission.php 